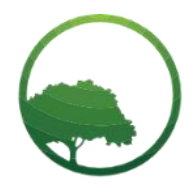

Research in Business \& Social Science

IJRBS VOL 10 NO 3 ISSN: 2147-4478

\title{
Covidomics \& covidocial impacts: The relation between consumers' fear of Covid-19, panic spending and saving behavior
}

\author{
Gul Ekinci
}

Social Science Institute, Gaziantep University, Gaziantep, Turkey

A R T I C L E I N F O
Article history:
Received 17 April 2021
Received in rev. form 27 April 202
Accepted 28 April 2021
Keywords:
Covid-19, Pandemic, Consumer
Behavior, Fear, Saving, Panic
Spending
JEL Classification:
D12, D91, M31, R2

\begin{abstract}
A B S T R A C T
In this study, the fear created by the Covid-19 global epidemic on consumers (general fear of viruses and fear of activity), spending (cleaning products, preventive health products, fresh and organic food and vitamin/mineral support, clothing, education, home purchasing, vehicle, loan. The relationship between buying, rental, fashion, vacation, travel, entertainment, electronics, home decor/furniture, mobile phone, activity and general) and savings have been tested. For this purpose, in order to test the relationship between fear, saving, and spending during the Covid-19 pandemic process, a Likert-scale online survey link was shared on social networks (Twitter, LinkedIn). The total of 385 surveys was analyzed using Google Form and SPSS program (Anova, Regression). As a result of the analysis, fear (general fear and fear of activity), spending (education, vehicles/cars, monopoly products, and tobacco products, games of chance, home buying and renting, loans, luxury/fashion, games, and toys, vitamins, minerals, and food support, public services, home, and furniture décor, electronic products (including mobile phones) expenditures remained the same, protective healthcare products, cleaning products, fresh and organic food expenditures increased, travel, public transportation expenditures decreased, holiday and entertainment expenditures decreased significantly). In the research, it was determined that $42 \%$ of the participants increased their savings by $30.5 \%$ slightly, and the amount of savings did not change at all for $27 \%$ of the participants. According to the results, as consumers' fear of Covid-19 increases, some spending categories (health products, cleaning products, fresh and organic food spending) and savings rate increase. In addition, it was observed that $90 \%$ of the participants canceled their expenses due to Covid-19. As a result of the research, significant relationships were found between the variables of fear, saving, and spending during the Covid-19 pandemic process.
\end{abstract}

(C) 2021 by the authors. Licensee SSBFNET, Istanbul, Turkey. This article is an open access article distributed under the terms and conditions of the Creative Commons Attribution (CC BY) license (http://creativecommons.org/licenses/by/4.0/).

\section{Introduction}

When we consider historical processes, it is known that humanity has confronted many disasters, wars, crisis and pandemics and also that these pandemics and disasters have had financial (covidomics) and social impacts (covidocial), at global scale. In the $21 \mathrm{st}$ century, this circulation hasn't changed by continuing to update itself.

In China, in December of 2019, the Covid-19 pandemic, which has triggered the most serious financial regression after the Second World War and the Great Depression (1930) and also which is accepted as the worst pandemic of this century, broke out (WHO, 2020). Anomalies have started to appear in every aspect of life. The buying behaviour of consumers, who have purchased irrationally and intiuitionally in many categories such as toilet paper, mask, dry food, cleaning and protective health products. It is a naturally expected result that a pandemic that is exposed globally have results at the global scale. The world's economic activities came down to $\% 6$ and production came down to \% 7.6; the OECD unemployment rate rose to \%9.2 from \%5.4 in 2019 and finally the GDP rate fell more than $\% 20$ all around the world in 2020 (OECD, 2020). The long-time effect of covidomics (covid-economics) has caused decrease in discretionary buying except from food, home and personal hygiene categories but it has caused price escalation in markets (Singh, 2020). This situation causes consumers to confront involuntary and compulsory saving and also to feel intensive worry in terms of their health, work and economy (Congressional Research Service, 2020). All this process has obliged consumers to meet

\footnotetext{
* Corresponding author. ORCID ID: 0000-0001-5512-4789

(C) 2021 by the authors. Hosting by SSBFNET. Peer review under responsibility of Center for Strategic Studies in Business and Finance. https://doi.org/10.20525/ijrbs.v10i3.1147
} 
'Pandemic Culture' that is a new but a tough culture and it has required adaptation. Being evolved by the uncertainty, consumers in fear of the pandemic are uneasy about spending money, thereby restricting themselves and trying to save (Sanjeev, 2020).

Covid-19 causes radical changes in income, production, finance, education, politics, tourism, daily life, work, the way and purpose of doing things. As socio-economic effects, covidomics change wind reflects on differentiating consumer behavior patterns and marketing activities through mirroring. Covidomics effects, which are expected to cause permanent changes in consumers' behaviors in the long term, reveal themselves in the habits of saving, consuming and spending

\section{Literature Review}

\section{Conceptual Background and Hypotheses Development}

Considering the grand scheme of things at global scale, it is expected that trade will fall between $\% 13-\% 16$, deeply affecting developed and developing markets and thereby, increasing the risk of global recession because of pandemic (Congressional Research Service, 2020). Nine consumers out of ten at global scale believe that Covid-19 will have very strong effects and, therefore, they change their buying habits in panic. While nearly eight consumers out of ten plan to delay their bigger buying, four out of ten have said that they will stop daily things that they buy and finally one third of them have emphasized that they will use their savings or diminish financial commitments like regular subscription (GWI, 2020:7-8).

Europe, consumption in many fields have become impossible and it goes down like a stone in free fall while spendable income have decreased between $\% 20$ and $\% 40$ and savings have increased during the quarantine period. Consumption have decreased $\% 35$ and household income between $\% 8$ and $\% 16$ while personal income have decreased between $\% 20$ and $\% 40$ (Boata et al., 2020). The rate of household saving has increased and spending has decreased in all EU member states according to the data regarding the first quarter of 2020 (EST, 2020). It has been observed that when considered psychologically, consumers have had higher levels of fear and depression together with decreasing income during Covid-19 (Harvard Business School, 2020).

It has been observed that many families go towards nearly zero consumption and they tend to save together with the concerns reasoned by uncertainty and fear and also with the contribution of social distancing in India (Sanjeev, 2020).

It is seen that the situation is not very different in EMEA region (Europe, Middle East, Africa). Consumers have reduced their spending from the most to the least in fields of holiday and travel, clothing, flight, vehicle and car, personal electronic, smart devices and insurance (Bland, 2020).

In the USA seventy percent of people under the effect of Covid-19, are worried about returning to out-of-home activities regular, joining the crowd and travelling with mass and flying (Arora et al., 2020).

It has been noticed that the most common fears among consumers are being infected by the virus, recession, inflation and security (Bharadwaj et al., 2020). Therefore, the notion that there will not be a fast transition to 'new normal' has been supported and delay of some buyings has shown that this effect will continue after the pandemic.

\section{Fear}

Consumer behaviors are the ones that are known as stimulated, dynamic, being effected by surrounding factors. Hedonic, pragmatic and emotional attitudes, fear of loss and uncertainty excessively activate consumers by motivating them (Odabaş1 and Barış, 2002). Customers' 'Impulsive Buying Behavior' (Unplanned Buying Behavior) causes sudden buying irrationally (Altunışı and Çallı, 2004: 231-240) and irrational and intensive buying become more and more intense in times of crisis.

The form of appearance of impulsive buying behaviors that come out in times of crisis and pandemics is accepted as 'excessive buying and stockpiling behaviors' that is reasoned by fear. This excessive buying and stockpiling behaviors can be based on the theories such as less is more valuable and quality (Romeo and Juliet Effect) and the effect of uncertainty ( Theort of Uncertainty) (Lidwel et al., 2006, Cialdini, 2006). Consumers' fear of joining activities related to the virus can be said to have been appeared as a result of excessive, offensive and autonomy-based buying behaviors -just like the example of toilet paper; fear of missing and bandwagon effect) (Euromonitor, 2020a; Child et al., 2020, Statista, 2020b,2020c).

It has been noticed that consumers, in fear and panic, tend to behaviors of buying and stockpiling food, cleaning and protective products during the process of Covid-19 (GWI, 2020:8; Harvard Business School, 2020, Işın, 2020a, Meyer, 2020, Genç,2020). The emerging result supports the theories that will be mentioned. Accordingly, the first hypothesis of the study H1;

H1: There is a relation between Covid-19 and fear.

\section{Fear of Activity}

The atmosphere of uncertainty emerged by the Covid-19 pandemic and also its high level of infectiousness have caused people to avoid activities and feel fear. Furthermore, consumers have had to delay their plans (GWI, 2020:8; Işın, 2020a). The rates of avoiding social activities (Child vd., 2020), joining activities and going to shopping malls (Marcos et al., 2020), cancelling hospital appointments (www.deloitte.com),being concerned about crowded events, mass transportation and air travel (Bacquet et al., 2020); and also trend toward robotic products in order to lower the risk of transmission have increased (www.euromonitor.com). It has been 
noticed that consumers waiting for the abolishment of prohibitons and restrictions (Catena et al., 2020) don't plan to visit stores (GWI, 2020:6-8). Digital activities (Child et al., 2020), teleconference, telemedicine, online conference, online fitness and the rates of digital channel usage have increased in comparison to pre-Covid-19 period (Grimmelt et al., 2020b). Generally, it can be said that there is a Covid-19-based fear of activity. Accordingly, H1a hypothesis of the study is:

H1a: There is a relation between the Covid-19 pandemic and fear of activity

\section{Fear of Virus}

In the crisis and disasters times customers' emotional behaviors, feeling of deprivation, fear of missing and uncertainty factors activate and motivate them. This excessive activation turns into panic buying, consumption frenzy and changes in habits (Sheth, 2020, Meyer, 2020; Addo et al.,2020:473; www.techinside.com; Odabaş1 and Barış, 2002). Covid-19 is one of these factors that cause excessive activation in consumers.

The Covid-19 pandemic, in general, has caused decrease in consumer spending (except from basic needs) and increased trend toward stockpiling on basic needs..(www.mckinsey.com).

When psychological states of consumers is considered, it has been noticed that they have higher levels of general financial concerns, expectations of recession, environmental cleaning, security, anxiety, state of depression and fear (Koslow, 2020a; Bharadwaj vd., 2020; McMullan vd., 2020; Schmidt et al., 2020; Alradhawi vd., 2020; Harvard Business School, 2020). It has been found that consumers' levels of concern about health, hygiene and social activities have increased (Euromonitor, 2020a; Koslow, 2020a). The fear that surrounded the whole world at the beginning of the pandemic has decreased in time. Besides, it has been noticed in the researches that fear and anxiety are still continuing and also that while optimism is increasing in China, New Zealand, Australia, Germany and South Africa, the number of optimists is decreasing in France, Italy, Singapore and Spain (GWI, 20207). Developing countries fear less in comparison the ones in the developed markets and they think more optimistically in terms of the future of economy (Bharadwaj et al., 2020).

In this study, the relation between the pandemic and fear (fear of activity, general fear of the virus) during the process of Covid-19 in Turkey has been tested. Accordingly, the study hypothesis is:

H1b: There is a relation between the Covid-19 pandemic and general fear of the virus.

\section{Consumer Spending}

In the crisis and disasters times customers' emotional behaviors, feeling of deprivation, fear of missing and uncertainty factors activate and motivate them. It is seen that consumers going through difficult times have been confronted with the options of not making a change, increasing or decreasing their spending according to their income. Difficult and hard times, in general, such as the Covid-19 pandemic, have globally changed the incomes, expectations and global consumption tendencies of consumers (BEA, 2020a). Panic and stress sometimes lead to increase in spending and desire of buying basic needs in times of uncertainty (Işın, 2020a), while they lead to decrease in desire of buying noncompulsory and easily reachable products (Durante and Laran, 2016; Bacquet et al., 2020; Chronopoulos, 2020).

Customers' financial concerns, expectations of recession, since consumers' panic and their having a feeling that they lose the control (Botti and McGill 2011) while passing through hard times such as war, disaster, illness. These situations known emerge as important factors in reducing consumption (Popper ve others) and the strategy that will be applied in terms of spending against these factors is up to consumers. For instance, consumption changed around \%90 in the USA in March 2020, internet shopping have increased in many countries including Turkey (Numerator Intelligence, 2020a; Işın 2020) and in a study that was carried out by TEPAV, it has been noticed that the importance of what is considered important and consumption spending have decreased \%34 in April in comparison to March. (TEPAV, 2020a). Furthermore e-trade increased (Pica, 2020), priorities changed, some concerns increased and finally houses started to become multifunctional by turning into office, gym, resting and entertainment places (BBC, 2020a). While consumers in developed markets plan to restrict their spending, the ones in developing countries have stated that they want to increase their spending quite oppositely (Bharadwaj et al., 2020). According to the data of TEPAV, there was increase in almost all spending items except insurance, electronic products Increases have been observed in especially casinos/places serving alcohol that were previously the ones effected most negatively, and also bar, night club, accommodation, food, renting car, clothing and accessory and construction in Turkey (TEPAV, 2020a). In the USA, the increasing rate for the age group of 60, who has shopped online for the first time, has risen to \%39 from \%5 (Numerator Intelligence, 2020a). Generally, serious increase in home entertainment (game, TV, film), music, book sales have been observed (Pica, 2020). In summary, consumer spending changes from country to country according to time, the progress of the pandemic and the level of fear.

In this study, the relation between the Covid-19 pandemic and consumer spending has been tested. Accordingly, the second hypothesis of the study is:

H2: There is a relation between the fear of Covid-19 and consumer spending. 


\section{Consumer Saving}

While the world is proceeding to be exposed to vital and financial chaos due to Covid-19, it doesn't seem possible for this chaos not to have effects on global economies and saving behaviors. Consumer incomes suffer from disruptions happening in the activities of production and service companies due to Covid-19, consumer behaviors change and individual savings are effected (www.statista.com). As it happens in the Covid-19 pandemic fear and stress are among the effective factors playing a role in reducing consumption (Popper et al, 1989), sometimes causing consumers increase their spending by activating them (Duhachek and Kelting 2009), sometimes causing them to decrease their spending (Blond, 2020), sometimes causing them to tend towards saving by passivizing it (Durante and Laran, 2016; www.mckinsey.com) and sometimes causing decline in saving rates (Bacquet et al., 2020). The studies of pandemic process proof it.

In the research that has been carried out by MX, it has been published that $2 / 3$ of consumers have changed their perception of 'saving' and $\% 34$ of them have started to save more in comparison to pre-pandemic process (Greer, 2020). In the research that has been carried out by Euromonitor, consumers have stated that they expect a recession period in economy and because of it they will freeze their spending (Euromonitor, 2020a). Bureau of Economic Analysis (BEA) announced the saving rate as \%32.2 that was \%12.6 in March and also the national saving rate reached its peak with $\% 33$ and finally BEA supported consumers' will of saving more (BEA, 2020a). According to the study carried out by Eurostat Statistics Explained, the rate of household saving increased in all EU countries in the first quarter of 2020 (EST, 2020). According the results of the studies, the interaction between saving and pandemic is attention grabbing.

In this study, the relation between the Covid-19 pandemic and consumer saving has been tested. Accordingly, the third hypothesis of the study:

H3: There is a relation between the fear of Covid-19 and consumer saving.

\section{Demographics Impacts on Consumers' Fear Of Covid-19, Panic Spending And Saving Behavior}

Consumer behavior and decision-making research was started 300 years ago according to Richarme (2007) by Nicholas Bernoulli, John von Neumann and Oskar Morgenstern who were economists (Bray, 2008: 2). Customer behavior, purchasing and consumption habit which is complex and a dynamic, descriptive and explanatory process is affected by psychological and demographic characteristics. Also several factor including socio-demographics affect consumer behavior during Covid-19 pandemic. Consumer behavior affected such as income (Throop, 1992; Kotler \& Armstrong, 2018), age (Harvey et al., 2001; Kotler \& Armstrong, 2018; Cranfield, 2020); gender (Blanchard et al., 2009; Aytekin \& Ekinci, 2014; Cranfield, 2020), education (Brown and Oplatka, 2020 ; Cranfield, 2020), anxiety or fear (Mansoor and Jalal, 2011: 104; Kikuchi et al, 2020). Many researchers found that more important changes have been observed in consumer behavior and consumptions habits during pandemic (Cranfield, 2020; Kikuchi et al, 2020). On the other hand as the spread of the Covid-19 pandemic all over the world, the fear of consumers increased, people began to exhibit consumer behavior in previous fear and crisis periods. They were introduced horrific pandemic culture and make panic purchases in with this fear and anxiety. People turn to basic needs that allow them to survive at the bottom of the pyramid according to Maslow's hierarchy of needs pyramid, in times of crisis. During this shock and crises period, consumer experience fear of not reaching basic needs and behavior tended towards products stockpiling of resources from panic buying (Loxton, 2020:3, 12, 14). At this point analyzing, and keeping track of consumer behavior or buying decision-making is critical and complex process (Bagozzi,GurhanCanli et al. 2002; Belch and Belch, 2004; Leone, Perugini et al. 2004) because of decoding the processes means that the information observed allows us to understand their need and increase profits of business (Radu, 2019).

In this context, we confirm order to measure the demographic effects on consumers' behavior (fear, panic spending, saving) during Covid-19 time. The following hypotheses are:

H4: Consumer spending (general) differs according to the demographic variables

H4a: Consumer spending differs according to the gender

H4aa: Spending on cleaning products differs according to the gender

H4ab: Spending on protective health products differs according to the gender

H4ac: Spending on off-licensed products differs according to the gender

H4ad: Spending on fresh/organic food\&vitamin/mineral differs according to the gender

H4ae: Spending on entertainment/travel/holiday and mass transportation differs according to gender

H4af: Spending on clothing differs according to gender

H4ag: The hypothesis that is 'Spending on education differs according to gender

H4ah: Spending on mobile phone differs according to gender variable

H4aj: Spending on electronics differs according to gender variable 
H4ak: Spending on home furniture and decoration differs according to gender

H4al: Spending on buying house, renting and loan differs according to gender

$\mathrm{H} 4 \mathrm{~b}$ : Consumer spending differs according to income

H4bb: Spending on off-licence products differs according to income

H4bc: Spending on fresh/organic food\&vitamin\&mineral differs according to income

H4bd: Spending on entertainment/travel/holiday and mass transportation differs according to income

H4be: The hypothesis that is 'Spending on clothing differs according to income

H4bf: Spending on education differs according to income

H4bg: Spending on mobile phone differs according to income

H4bh: The hypothesis that is 'Spending on electronic differs according to income

H4bk: Spending on house furniture and decoration differs according to income

H4bl: Buying house, renting and loan spending differ according to income

H4bm: Spending on cleaning products differs according to income

H4bn: Spending on preventive health products differs according to income

$\mathrm{H} 4 \mathrm{c}$ : Consumer spending differs according to education

H4cc: Spending on off-licence products differs according to education level'

H4cd: Spending on fresh/organic food\&vitamin/mineral differs according to income

H4ce: Spending on entertainment/travel/holiday and mass transportation differs according to education

H4cf: Spending on clothing differs according to education

$\mathrm{H} 4 \mathrm{cg}$ : The hypothesis that is' Spending on education differs according to education

H4ch: Spending on mobile phone differs according to education

H4ci: Spending on electronic products differs according

H4ck: Spending on house furniture and decoration differs according to education

$\mathrm{H} 4 \mathrm{cl}$ : Buying house, renting, loan spending differ according to education

$\mathrm{H} 4 \mathrm{~cm}$ : Spending on cleaning products differs according to education

$\mathrm{H} 4 \mathrm{cn}$ : Spending on preventive health products differs according to education

H4d: Consumer spending differs according to age

H4dd: Spending on off-license products differs according to age

H4de: Spending on fresh, organic food, vitamin and mineral differs according to age

H4df: Spending on entertainment/travel/holiday and mass transportation differs according to age

H4dg: Spending on clothing differs according to age

H4dh: Spending on education differs according to age

H4di: Spending on mobile phone differs according to age

H4dk: Spending on electronic differs according to age

H4dm: Buying house, renting, loan spending differ according to age

H4dn: Spending on cleaning products differs according to age

H4dp: Spending on preventive health products differs according to age

H5: Consumer savings differ according to demographic

H5a: Consumer savings differ according to gender 
H5b: Consumer saving differs according to income

H5c: Consumer saving differs according to education

H5d: Consumer saving differs according to age

H6: General fear of Covid-19 differs according to demographic variables

H6a: Fear of the virus differs according to gender

H6b: The hypothesis that is 'Fear of the virus differs according to income

H6c: The hypothesis that is 'Fear of the virus differs according to education

H6e: The hypothesis that is 'Fear of activity differs according to gender

H6d: Fear of the virus differs according to age

H6f: Fear of activity differs according to income

H6g: Fear of the virus differs according to education variable

H6h: Fear of activity differs according to age

\section{Research and Methodology}

The subjects in this research are consumers in Turkey. Turkey's population is 83.154 .997 and has been accepted as the main population. The number of samples was determined using the online sample size calculator for Slovin's formula

$\mathrm{n}=\mathrm{N} /(1+\mathrm{Ne} 2)$

Where :

$\mathrm{n}=$ total samples

$\mathrm{N}=$ total population

$\mathrm{e}=$ error tolerance limit $(5 \%)$

The calculation by using $50 \%$ as the worst case percentage for the sample size the calculation using the formula resulted in 385 samples. The sampling technique used simple random sampling. It has been calculated that confidence interval should be $5 \%$, confidence level $95 \%$ and the number of minimum sample 385. After deleting the outliers and missing data the remaining 385 data from 413 questionnaires were analyzed.

An online survey based well-structured questionnaire was developed using with Google forms as it is considered a cost-effective and reliable data source for research marketing and conducted to test research hypotheses. An online form Google form shared with the respondent to distribute the questionnaire using by social media and e-mail. Convenience sampling was used on sample. The research targeted residents aged over 18 in Turkey and respondents have participated voluntarily in this study. When this study started there is no study examining fear, spending and saving issues about that first Covid-19 case seem on March. The nationwide lockdown started in Turkey on 10th April 2020 to limit the movement of the population and survey was send to participates from 1 st May 2020 to 30th May 2020. We examined fear, spending and saving behavior related to three behavior: vehicle/mass transportation/holiday/entertainment/games of chance, fresh food and cleaning products, clothing (woman, man, child), general fear of the virus, fear of activity (shopping /travel/entertainment, going out) during Covid-19 pandemic.

\section{Data Analysis Technique}

Where :

$\mathrm{Y}=$ Variable of Covid-19 Impact on Consumer Behavior

$\mathrm{a}=$ Constant

b1, b2, b3 = Regression Coefficient

$\mathrm{X} 1$ = Variable of Fear of Covid-19

$\mathrm{X} 2$ = Variable of Saving Behavior X3 = Variable of Spending Behavior

$\mathrm{e}=$ Standard Error (error rate) $5 \%$

BCG (Boston Consultant Group) and McKinsey \& Company's online survey questions used for to measure the variables. The questions were administrated on a Likert 5-point scale ranging from ' $1=$ extremely strongly disagree' to $5=$ extremely strongly agree'. The measurement items are provided in Appendix 1 and the questionnaire was pilot tested. The hypotheses have been tested 
by factor analysis and also regression analysis and reliability test have been applied. The results showed adequate internal consistency reliability (with Cronbach's alpha $=0.934$ and the intra-class correlation coefficient was 0.987 ).

There are 8 (eight) assumption test for this research results.

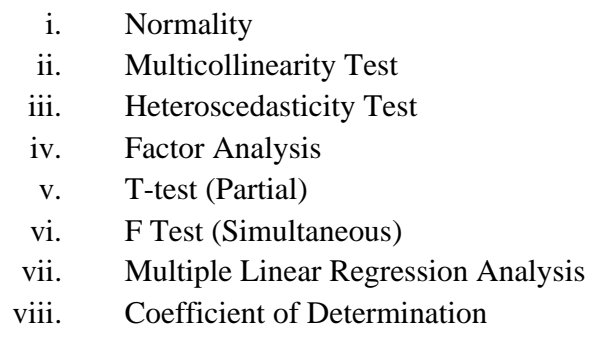

The sampling technique used simple random sampling.

\section{Result and Discussion}

\section{Normality}

Below is the result of normality test using the histogram of standardized residuals compares the distrubition of the residuals to a normal distribution from the variables of fear of virus, fear of activity, saving behavior and spending behavior. The smooth line represents the normal distribution. The close the frequencies of the residuals are to this line, the closer the distribution of the residuals is to the normal distribution.

Figure 1: Histogram

Based on the image of the results of the above SPSS output, histogram diagram formed rounded normal curve and thus the residual is declared normal and normality assumption is met. Other data normality test in this research used histogram and graphics (Normal P-P Plots).

Figure 2: Normal P-P Plots

From the above figure, it can be seen that the points or data are unidirectional and follow the diagonal lines. This can be concluded that the data are normally distributed. 
Table 1: Skewness and Kurtosis Test

\begin{tabular}{lllll}
\hline Statistics & & & \\
\hline $\mathbf{N}$ & & Fear & Spending & Saving \\
\hline \multirow{2}{*}{ Mean } & Valid & 385 & 385 & 384 \\
\cline { 2 - 5 } Median & Missing & 0 & 0 & 1 \\
\hline Std. Deviation & 3,8850 & 2,66 & 3,11 \\
\hline Skewness & 4,1429 & 2,67 & 3,00 \\
\hline Std. Error of Skewness & 0,89951 & 0,554 & 1,141 \\
\hline Kurtosis & $-1,051$ & 0,095 & $-0,242$ \\
\hline Std. Error of Kurtosis & 0,124 & 0,124 & 0,125 \\
\hline Based & 0,823 & 1,050 & $-0,790$ \\
\hline
\end{tabular}

Based on the data on the table above, the variable of fear, saving, spending the value of skewness and kurtosis between of -2 and +2 thus declared as normally distributed.

\section{Multicollinearity Test}

The results of data processing from multicollinearity test is presented in the following table:

Table 2: Multicollinearity Test

\begin{tabular}{|c|c|c|c|c|c|}
\hline \multirow[b]{2}{*}{ Model } & \multicolumn{3}{|l|}{ Correlations } & \multicolumn{2}{|c|}{ Collinearity Statistics } \\
\hline & The Zero-order & Partial & Part & Tolerance & VIF \\
\hline 1 & ,934 (Fear) & ,934 & ,934 & 1,000 & 1,000 \\
\hline \multirow[t]{4}{*}{2} & ,934 (Fear) & ,906 & ,756 & ,707 & 1,415 \\
\hline &, 546 (Fear of Activity) & 144 &, 052 & ,707 & 1,414 \\
\hline & ,051(Spending) &, 020 & ,007 & ,997 & 1,003 \\
\hline & ,141(Saving) & 015 &, 005 & ,974 & 1,026 \\
\hline
\end{tabular}

The above table shows that no the tolerance value under $10 \%$ and the value of Variance Inflation Factor (VIF) is no more than 10 , which indicates that this regression model of these variables shows no multicollinearity problems.

\section{Heteroscedasticity Test}

How to predict heteroscedasticity in a model can be seen using Scatter plot pattern below :

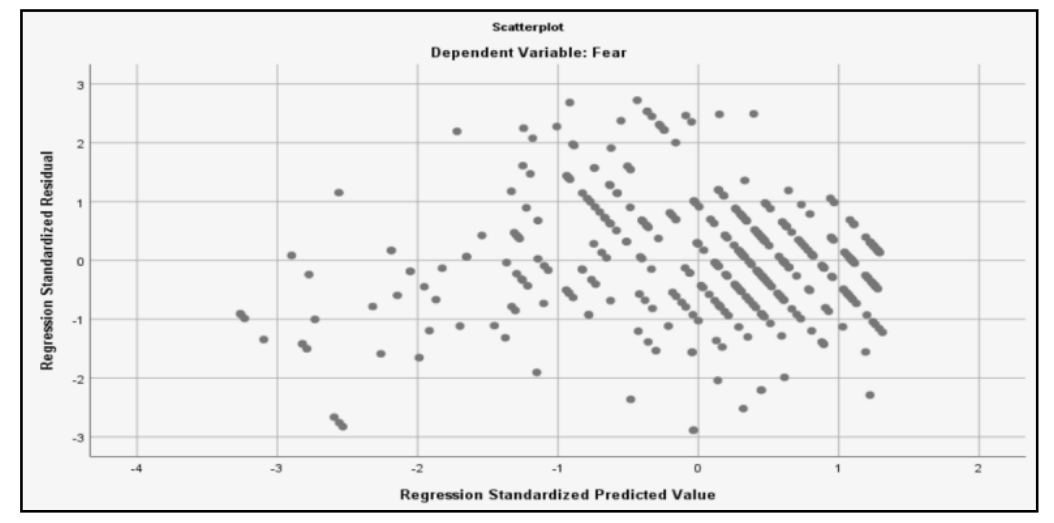

Figure 3: Heteroscedasticity test.

From the above figure, it is seen that the points are spread at random and spread out above or under 0 on the $\mathrm{Y}$ axis. It is concluded that heteroscedasticity does not occur in a regression model leaving the regression model feasible to predict consumer behavior based on variable of spending and saving, the fear of virus and fear of activity.

\section{Factor Analysis}

Exploratory factor analysis was used to check the factor structure of the research items. The sample adequacy was tested using Kaiser-Meyer-Olkin (KMO) and Bartlett's test of sphericity. The KMO (0.874) value was good and Bartlett's test of sphericity $(\chi 2=51823,915 \mathrm{df}=8778, \mathrm{p}<.001)$ was significant. This result implying that the present research has an adequate sample size and correlations among some of the items. The rotated component matrix was used from these 30 items; one component was extracted and remains were able to explain $70.533 \%$ of the variability in the data. 
Table 3: T-test Results of Factor Analysis (Scale's Croanbach's Alpha:0,934) Coefficients

\begin{tabular}{|c|c|c|c|}
\hline & Spending & Saving & Fear \\
\hline & $\begin{array}{l}\text { Cronc. Alph } \\
, 943\end{array}$ & $\begin{array}{l}\text { Cron. Alph } \\
, 869\end{array}$ & $\begin{array}{l}\text { Cron. } \\
\text { Alph } \\
\text {,974 }\end{array}$ \\
\hline Vehicle/Mass transportation / Holiday / Entertainment / Games of chance & ,816 & & \\
\hline \multicolumn{4}{|l|}{$\begin{array}{l}\text { In what way have your spendings below changed in the last three months due to the } \\
\text { Covid-19 pandemic? } \\
1=\text { Decreased a lot, } 2=\text { Decreased, } 3=\text { Not changed, } 4=\text { Increased, } 5=\text { Increased a lot }\end{array}$} \\
\hline H15F. Vehicle/Automobile & 878 & & \\
\hline H15L. Games of chance & 878 & & \\
\hline H15M. Travel & 877 & & \\
\hline H15P. Mass transportation & 876 & & \\
\hline H15R. Public services & 874 & & \\
\hline H15S. Holiday and entertainment & 876 & & \\
\hline Fresh Food and Cleaning Products & ,720 & & \\
\hline H16B & 871 & & \\
\hline $\mathrm{H} 16 \mathrm{C}$ & 870 & & \\
\hline H16D & 872 & & \\
\hline Clothing (Woman, Man, Child) & 874 & & \\
\hline H15AA & 877 & & \\
\hline H15BB & 875 & & \\
\hline $\mathrm{H} 15 \mathrm{CC}$ & 877 & & \\
\hline $\begin{array}{l}\text { *SAVING } 1=\text { Absolutely disgaree } 2=\text { Disagree } 3=\text { Indecisive } 4=\mathrm{I} \text { agree } 5= \\
\text { Absolutely agree }\end{array}$ & & ,869 & \\
\hline H7.I've decreased my daily spending due to Covid-19 & & ,873 & \\
\hline \multicolumn{4}{|l|}{$\begin{array}{l}1=\text { Decreased a lot } 2=\text { Decreased } 3=\text { Not changed } \\
4=\text { Increased } 5=\text { Increased a lot }\end{array}$} \\
\hline $\begin{array}{l}\text { H15A.In what way have your savings changed in the last three months due to the } \\
\text { Covid-19 pandemic? }\end{array}$ & & 0,873 & \\
\hline \multicolumn{4}{|l|}{$1=$ Very little $2=$ Little $3=$ Not changed $4=$ Much 5=Very much } \\
\hline H17. Did you increase your savings due to the Covid-19 pandemic? & & 875 & \\
\hline $\begin{array}{l}\text { *FEAR } 1=\text { Absolutely disagree } 2=\text { Disagree } 3=\text { Indecisive } 4=\mathrm{I} \text { agree } 5=\text { Absolutely } \\
\text { agree }\end{array}$ & & & ,974 \\
\hline General Fear of the Virus & & & 870 \\
\hline K2. I am afraid of being infected by the Covid-19 virus most & & & 883 \\
\hline K4. The world is under a serious threat due to the Covid-19 pandemic & & & 871 \\
\hline $\begin{array}{l}\text { K5.I try to escape from crowded places as much as possible due to the Covid-19 } \\
\text { pandemic }\end{array}$ & & & 870 \\
\hline K6. The Covid-19 pandemic has caused me to change my daily life & & & ,895 \\
\hline Fear of Activity (Shopping /Travel/Entertainment/Going out) & & & ,974 \\
\hline K12. Are you worried about doing the daily activities below? & & & ,970 \\
\hline A. Travelling internationally & & & ,969 \\
\hline B.Domestic flight & & & ,966 \\
\hline C.Voyage & & & ,969 \\
\hline D.Travelling by bus, tramor train & & & ,970 \\
\hline E.Staying at a hotel & & & ,970 \\
\hline F.Taking a taxi & & & ,971 \\
\hline G.Going to a restaurant & & & ,972 \\
\hline H.Visiting shopping stores & & & ,972 \\
\hline M.Going to entertainment centers & & & ,974 \\
\hline
\end{tabular}

The confirmatory factor analysis was used to test the reliability and validity of the constructs. The construct validity of the instrument was explained by convergent validity and discriminate validity. The convergent validity was assessed using Cronbach's alpha $(\alpha)$, Composite reliability (CR), and statistical significance of the item factor loadings ( $\beta$; Hair et al.,2010). Results provided in Table 5.2 show that item factor loadings $(\beta)$ were higher than 0.5 and the factor rates are high. Cronbach alpha coefficients obtained from all 
the dimensions range from 0.720 to 0.974 and the composite reliability ranged from 0.869 to 0.974 . These high values indicate that the survey questions that have been used to measure the variables provide conceptual integrity, and the variables have been uploaded correctly and supporting the convergent validity and only items with a factor load above 0.6 were retained finally.

\section{T-test (Partial)}

The t-test used to test whether there is a significant impact between independent variables and dependent variables separately.

Table 4: T-test Coefficients

\begin{tabular}{|c|c|c|c|c|c|c|}
\hline \multicolumn{7}{|c|}{ Dependent Variables: Spending/Saving/Fear T-tests Coefficients } \\
\hline & $\mathrm{N}$ & Mean & Std. Dev. & df & $\mathrm{t}$ & Sig. \\
\hline \multicolumn{7}{|c|}{ Spending on Cleaning Products } \\
\hline Woman & 229 & 3,8603 & ,67912 & 383 & 2,508 & $\mathbf{0 , 0 1 3}$ \\
\hline Man & 156 & 3,6619 & 86965 & 277,923 & 2,395 & $\mathbf{0 , 0 1 7}$ \\
\hline \multicolumn{7}{|c|}{ Spending on Protective Health Products } \\
\hline Woman & 229 & 3,9803 & 83288 & 383 & 1,855 & 064 \\
\hline Man & 156 & 3,7981 & 1,09217 & 273,009 & 1,764 & 079 \\
\hline \multicolumn{7}{|c|}{ Spending on Off-Licence Products } \\
\hline Woman & 229 & 2,4061 & ,97498 & 383 & $-1,372$ &, 171 \\
\hline Man & 156 & 2,5481 & 1,02828 & 321,12 & $-1,358$ &, 175 \\
\hline \multicolumn{7}{|c|}{ Spending on Fresh/Organic Food\&Vitamin/Mineral } \\
\hline Woman & 229 & 3,5721 & ,73056 & 383 & 3,134 & $\mathbf{0 , 0 0 2}$ \\
\hline Man & 156 & 3,3243 & ,80498 & 311,142 & 3,077 & $\mathbf{0 , 0 0 2}$ \\
\hline \multicolumn{7}{|c|}{ Spending on Entertainment/(Travel/Holiday/Mass Transportation) } \\
\hline Woman & 229 & 1,7915 & 83241 & 383 &,- 002 & ,998 \\
\hline Man & 156 & 1,6769 & ,75179 & 354,104 &,- 002 & ,998 \\
\hline \multicolumn{7}{|c|}{ Spending on Clothing } \\
\hline Woman & 229 & 2,3947 & ,96766 & 382 & 1,225 & 221 \\
\hline Man & 156 & 2,2756 & 88583 & 351,454 & 1,246 & ,224 \\
\hline \multicolumn{7}{|c|}{ Spending on Education } \\
\hline Woman & 229 & 2,7083 & ,70821 & 382 & 1,175 & 241 \\
\hline Man & 156 & 2,6186 & ,77275 & 313,621 & 1,156 & ,249 \\
\hline \multicolumn{7}{|c|}{ Spending on Mobile phone } \\
\hline Woman & 229 & 2,9298 & 1,05023 & 382 & 1,091 & ,276 \\
\hline Man & 156 & 2,8141 & ,97587 & 348,544 & 1,106 & 269 \\
\hline \multicolumn{7}{|c|}{ Spending on Electronic } \\
\hline Woman & 229 & 2,5461 & ,99617 & 382 & ,264 & ,792 \\
\hline Man & 156 & 2,5192 & ,95357 & 342,504 & ,266 & ,791 \\
\hline \multicolumn{7}{|c|}{ Spending on Home Furniture and Decoration } \\
\hline Woman & 229 & 2,2390 & ,94385 & 382 &,- 393 & 694 \\
\hline Man & 156 & 2,2756 & ,82167 & 360,547 &,- 403 & 687 \\
\hline \multicolumn{7}{|c|}{ Spending on Buying house, Renting, Loan } \\
\hline Woman & 229 & 2,2632 & ,94382 & 382 &,- 862 & ,389 \\
\hline Man & 156 & 2,3462 & ,90092 & 343,088 &,- 870 & ,385 \\
\hline \multicolumn{7}{|c|}{ Consumer Saving } \\
\hline Woman & 229 & 3,3231 & ,79924 & 383 & $-, 2,104$ & 0,926 \\
\hline Man & 156 & 3,3312 & ,88759 & 332,923 & $-2,101$ & 0,928 \\
\hline \multicolumn{7}{|c|}{ Fear of the Virus } \\
\hline Woman & 229 & 4,2522 & ,72054 & 383 & 5,692 & $\mathbf{0 , 0 0}$ \\
\hline Man & 156 & 3,7372 & 1,05525 & 276,355 & 5,310 & $\mathbf{0 , 0 0}$ \\
\hline \multicolumn{7}{|c|}{ Fear of Activity } \\
\hline Woman & 229 & 4,0223 & 1,05350 & 383 & 5,137 & $\mathbf{0 , 0 0}$ \\
\hline Man & 156 & 3,3953 & 1,33556 & 279,682 & 4,914 & $\mathbf{0 , 0 0}$ \\
\hline \multicolumn{7}{|c|}{ General fear of Covid-19 } \\
\hline Woman & 229 & 4,0928 & ,86238 & 383 & & $\mathbf{0 , 0 0}$ \\
\hline Man & 156 & 3,5005 & 1,10986 & 276,880 & 5,611 & $\mathbf{0 , 0 0}$ \\
\hline
\end{tabular}

Note: Dependent Variables: Fear of virus, Fear of Activity, Spending and Saving 
H4: The hypothesis that is 'Consumer spending (general) differs according to the demographic variables' has been accepted. There is a statistically meaningful difference between consumer spending of woman and man consumers participating in the study.

H4a: The hypothesis that is 'Consumer spending differs according to the gender variable' has been accepted. There is a statistically meaningful difference between consumer spending of women and men participating in the study according to their genders.

H4aa: The hypothesis that is 'Spending on cleaning products differs according to the gender variable' has been accepted. There is a statistically meaningful difference between cleaning products spending of women and men participating in the study according to their genders.

H4ab: The hypothesis that is 'Spending on protective health products differs according to the gender variable' has been rejected. There isn't a statistically meaningful difference between protective health products spending of woman and man consumers participating in the study according to their genders.

H4ac: The hypothesis that is 'Spending on off-licence products differs according to the gender variable' has been rejected. There isn't a statistically meaningful difference between off-licence products spending of woman and man consumers participating in the study according to their genders.

H4ad: The hypothesis that is 'Spending on fresh/organic food\&vitamin/mineral differs according to the gender variable' has been accepted. There is a statistically meaningful difference between fresh/organic food\&vitamin/mineral spending of men and women consumers participating in the study according to their genders. The results show that the spending average of women is higher than that of men.

H4ae: The hypothesis that is 'Spending on entertainment/travel/holiday and mass transportation differs according to gender variable' has been rejected. There isn't a statistically meaningful difference between entertainment/travel/holiday and mass transportation spending of man and woman consumers participating in the study considering their gender.

H4af: The hypothesis that is 'Spending on clothing differs according to gender variable' has been rejected. There isn't a statistically meaningful difference between clothing spending of man and woman consumers participating in the study considering their gender. H4ag: The hypothesis that is 'Spending on education differs according to gender variable' has been rejected. There isn't a statistically meaningful difference between educational spending of man and woman consumers participating in the study considering their genders.

H4ah: The hypothesis that is 'Spending on mobile phone differs according to gender variable' has been rejected. There isn't a statistically meaningful difference between mobile phone spending of man and woman consumers participating in the study considering their genders.

H4aj: The hypothesis that is 'Spending on electronics differs according to gender variable' has been rejected. There isn't a statistically meaningful difference between electronic products spending of man and woman consumers participating in the study considering their genders.

H4ak: The hypothesis that is 'Spending on home furniture and decoration differs according to gender variable' has been rejected. There isn't a statistically meaningful difference between home furniture and decoration spending of man and woman consumers participating in the study considering their genders.

H4al: The hypothesis that is 'Spending on buying house, renting and loan differs according to gender variable' has been rejected. There isn't a statistically meaningful difference between buying house, renting and loan spending of man and woman consumers participating in the study considering their genders.

In summary, in this study, the hypotheses of H4, H4a, H4aa, H4ad have been accepted and the hypotheses of H4ab, H4ac, H4ae, H4af, H4ag, H4ah, H4aj, H4ak, H4al have been rejected. Consumer spending (general) and spending on preventive health products, off-license products, entertainment/travel/holiday and mass transportation, clothing, education, electronic products, home furniture and decoration, buying house, renting and loan and consumer saving of men and women consumers participating in the study don't differ statistically between the genders. Accordingly, the both groups (men and women) don't exhibit different spending habits in terms of their spending on preventive health products, off-license products, entertainment/travel/holiday and mass transportation, clothing, education, electronic products, home furniture and decoration, buying house, renting and loan.

In the study, spending on cleaning products, fresh/organic food\&vitamin/mineral and also the fear of the virus and fear of activity show statistical difference in term of gender. The mean of cleaning products spending is 3,8603 for women and 3,6619 for men. The mean of fresh/organic food\&vitamin/mineral spending is 3,5721 for women and 3,3243 for men.

In the study, the fear of the virus has differed statistically among the consumers participating in the study in terms of gender and it has been noticed that the mean of fear of the virus is 4,2522 for women and 3,7372 for men. Fear of activity differs statistically among the consumers participating in the study in terms of gender and the mean of fear of the virus is 4,0223 for women and 3,3953 for men. Fear of the activity differs statistically among the consumers participating in the study in terms of gender and the mean of fear of activity in terms of gender is 4,0223 for women and 3,3953 for men. Additionally, fear of Covid-19 differs statistically 
according to demographic variables. The mean of fear of Covid-19 in terms of gender is 4,0928 for women and 3,5005 for men. It is seen that the means of fear for women are higher than that of men.

H5a: The hypothesis that is 'Consumer savings differ according to gender variable' has been rejected. When the study is examined in terms of consumer saving, there is no difference related to gender.

H6: The hypothesis that is 'General fear of Covid-19 differs according to demographic variables' has been accepted. There is statistical difference between consumers' fear of Covid-19 and gender groups during the Covid-19 period as seen in Table 4 . Therefore, fear of Covid-19 differs according to demographic variables. It is seen that the mean of general fear of Covid-19 for men $(3,5005)$ is lower than that of women $(4,0928)$.

H6a: The hypothesis that is 'Fear of the virus differs according to gender variable' has been accepted. There is statistical difference between consumers' fear of Covid-19 and gender groups during the Covid-19 period as seen in Chart 5.5. Therefore, fear of the virus differs according to genders. The mean of fear of the virus is 4,252 for women and 3,7372 for men.

H6e: The hypothesis that is 'Fear of activity differs according to gender variable' has been accepted. There is statistical difference between consumers' fear of activity and gender groups during the Covid-19 period as seen in Chart 5.5. Therefore, fear of activity differs according to genders. The mean values of fear of activity is 4,0223 for women and 3,3953 for men. In summary, the hypotheses of H6, H6a, H6e have been accepted and H5a has been rejected.

\section{F Test (Simultaneous)}

Below are the results of hypothesis tests simultaneously from the variables in this research:

Table 5a: F Test

\begin{tabular}{lllllll}
\hline ANOVA $^{\mathbf{a}}$ & & & & & \\
Model & & Sum of Squares & df & Mean Square & F & Sig. \\
\hline $\mathbf{1}$ & Regression & 249,199 & 1 & 249,199 & 2598,999 &, $000 \mathrm{~b}$ \\
\cline { 2 - 7 } & Residual & 36,627 & 382 &, 096 & & \\
\cline { 2 - 7 } & Total & 285,826 & 383 & & $600 \mathrm{c}$ & \\
\hline \multirow{2}{*}{} & Regression & 250,004 & 4 & 62,501 & & \\
\cline { 2 - 8 } & Residual & 35,822 & 379 & 695 & & \\
& Total & 285,826 & 383 & & & \\
\end{tabular}

a. Dependent Variable: Consumer Behavior

b. Predictors: (Constant), Fear
c. Predictors: (Constant), Fear, Spending, Saving and Fear of Activity

The total of FTable in this Model 1 and Model 2 research is as follows: The above table shows that the value of $\mathrm{F}_{\text {model }}$ count is 2598,999 and $F_{\text {model } 2}$ count is 661,501 with probability 0,000. Since its probability is smaller than 0.05 and Ho is rejected or Ha is accepted which means that variables of fear, spending, saving and fear of activity have a significant effect on consumer behavior.

Table 5b: F Test (spending)

\begin{tabular}{|c|c|c|c|c|c|}
\hline & SPENDING ( & & & & \\
\hline \multirow[t]{2}{*}{ Educ. Lev } & $\begin{array}{l}\text { Fresh organic } \\
\text { Food } \\
\text { Vitamin } \\
\text { Mineral }\end{array}$ & $\begin{array}{l}\text { Entertainment } \\
\text { Travel } \\
\text { Holiday } \\
\text { MassTransportation }\end{array}$ & $\begin{array}{l}\text { Spending } \\
\text { On Clothing }\end{array}$ & $\begin{array}{l}\text { House } \\
\text { Furniture } \\
\text { Decoration }\end{array}$ & Elektronics \\
\hline & $\begin{array}{l}\text { Lev.S: ,337 } \\
\text { F:1,008 } \\
\text { Sig:,002 }\end{array}$ & $\begin{array}{l}\text { Lev.S: ,001 } \\
\text { F:2,835 } \\
\text { Sig:,016 }\end{array}$ & $\begin{array}{l}\text { Lev.S ,337 } \\
\text { F: } 1,008 \\
\text { Sig:,413 }\end{array}$ & $\begin{array}{l}\text { Lev.S ,956 } \\
\text { F:2,326 } \\
\text { Sig:,042 }\end{array}$ & $\begin{array}{l}\text { Lev.S,555 } \\
\text { F:,3,032 } \\
\text { Sig:,011 }\end{array}$ \\
\hline HighSchool/ Below & 3,4628 & 1,6959 & 3,4628 & 2,2770 & 2,3986 \\
\hline Associate degree & 3,5431 & 1,8276 & 3,5431 & 2,2500 & 2,5893 \\
\hline Uni. student & 3,5004 & 1,7784 & 3,5004 & 2,2809 & 2,6289 \\
\hline Bachelor's degre & 3,2976 & 1,4524 & 3,2976 & 2,1190 & 2,3968 \\
\hline Master degree & 3,5833 & 1,3889 & 3,5833 & 2,6667 & 2,8889 \\
\hline Phd & 3,7500 & 1,000 & 3,7500 & 1,4286 & 1,5000 \\
\hline Average & 2,8978 & 1,3572 & 3,5228 & 2,2539 & 2,5352 \\
\hline Age & $\begin{array}{l}\text { Lev.S: ,649 } \\
\text { F:,833 } \\
\text { Sig:,0050 }\end{array}$ & $\begin{array}{l}\text { Lev.S:,001 } \\
\text { F:2,845 } \\
\text { Sig:,001 }\end{array}$ & $\begin{array}{l}\text { Lev.S:,007 } \\
\text { F:2,392 } \\
\text { Sig:0,068 }\end{array}$ & $\begin{array}{l}\text { Lev.S:,851 } \\
\text { F:1,355 } \\
\text { Sig:,256 }\end{array}$ & $\begin{array}{l}\text { Lev.S ,084 } \\
\text { F:4,137 } \\
\text { Sig:,007 }\end{array}$ \\
\hline
\end{tabular}




\begin{tabular}{llllll}
\hline Table Cont'd & \multicolumn{5}{l}{} \\
\hline Gen. Z (18-25y) & 3,4692 & 1,7420 & 2,3369 & 2,2544 & 2,5979 \\
\hline Gen. Y (26-40y) & 3,4524 & 1,5711 & 2,3494 & 2,3313 & 2,4578 \\
\hline Gen. X (41-54y) & 3,4853 & 1,3235 & 2,0196 & 1,8529 & 1,7941 \\
\hline Baby B. (55+y) & 4,1667 & 1,0000 & 1,000 & 2,3333 & 3,0000 \\
\hline Mean & 3,4716 & 1,6805 & 2,3151 & 2,2539 & 2,5332 \\
\hline Inc. & Lev.S:,881 & Lev.S:,010 & Lev.S:,330 & Lev.S:,712 & Lev.S,892 \\
Level (TL) & F:2,323 & F:2,388 & F:,261 & F:, 1,472 & F: 1,261 \\
& Sig:,043 & Sig:,038 & Sig:,934 & Sig:,198 & Sig:,280 \\
\hline No income & 3,33 & 1,9184 & 2,4218 & 2,2347 & 2,6091 \\
\hline 2500 or below & 3,67 & 1,7640 & 2,2937 & 2,3571 & 2,2895 \\
\hline $2501-5000$ & 3,76 & 1,6136 & 2,3182 & 2,0682 & 2,6250 \\
\hline $5001-7500$ & 3,83 & 1,5678 & 2,3161 & 2,1121 & 2,4115 \\
\hline $7501-10000$ & 3,62 & 1,3571 & 2,3494 & 2,4286 & 2,2500 \\
\hline $10001 /$ Over & 3,36 & 1,4310 & 2,2184 & 2,2931 & 2,6667 \\
\hline General & 3,64 & 1,6805 & 2,3151 & 2,2539 & 2,5352 \\
\hline
\end{tabular}

H4b: The hypothesis that is 'Consumer spending differs according to income variable' has been accepted. There is statistical difference between consumer spending and income level during the Covid-19 period as seen in Chart 5.7. Therefore, the difference between consumer spending and income group is \% 5 (p:0,000) meaningful and it changes according to income.

H4bc: The hypothesis that is 'Spending on fresh/organic food\&vitamin\&mineral differs according to income variable' has been accepted. In other words consumers in different income groups among the participants exhibit different behaviors in term of spending on fresh/organic food\&vitamin\&mineral.

H4bd: The hypothesis that is 'Spending on entertainment/travel/holiday and mass transportation differs according to income variable' has been accepted. There are differences among the consumers in different income levels regarding spending on entertainment/travel/holiday and mass transportation. The participants' spending on spending on entertainment/travel/holiday and mass transportation differs according to income level.

H4be: The hypothesis that is 'Spending on clothing differs according to income variable' has been accepted. \%1 statistically meaningful relation hasn't been found between spending on clothing and income. In the study, spending on clothing doesn't change according to income among the consumers.

H4bh: The hypothesis that is 'Spending on electronic differs according to income variable' has been rejected. \%1 statistically meaningful relation hasn't been found between spending on electronic and income. In the study, spending on electronic doesn't show difference according to income among the consumers.

H4bk: The hypothesis that is 'Spending on house furniture and decoration differs according to income variable' has been rejected. $\% 1$ statistically meaningful relation hasn't been found between spending on house furniture and decoration and income. In the study, spending on house furniture and decoration doesn't show difference according to income among the consumers.

H4c: The hypothesis that is 'Consumer spending differs according to education variable' has been accepted. Consumer spending differs among the participants in different education levels. There is a meaningful relation between participants' spending and education levels.

H4cd: The hypothesis that is 'Spending on fresh/organic food\&vitamin/mineral differs according to income variable' has been accepted. In other words, There are differences among the participants regarding the relation between spending on fresh/organic food\&vitamin/mineral and education variable. It is seen that the education level spending on fresh/organic food\&vitamin/mineral most is consumers with Phd degree.

H4ce: The hypothesis that is 'Spending on entertainment/travel/holiday and mass transportation differs according to education variable' has been accepted. It is seen that the educated consumer group with $\mathrm{PhD}$ degree is the one spending on entertainment/travel/holiday and mass transportation least.

H4cf: The hypothesis that is 'Spending on clothing differs according to education variable' has been rejected. \%1 statistically meaningful relation hasn't been found between spending on clothing and education level. In the study, spending on clothing doesn't change according to education among the consumers.

H4ci: The hypothesis that is 'Spending on electronic products differs according to education variable' has been accepted. It is seen that the education level spending on electronic products least is the one with $\mathrm{PhD}$ degree. 
H4ck: The hypothesis that is spending on house furniture and decoration differs according to education variable' has been accepted. It is seen that the education level spending on house furniture and decoration least is the one with $\mathrm{PhD}$ degree.

H4d: The hypothesis that is 'Consumer spending differs according to age' has been accepted. There is statistical difference between consumer spending and their age during the Covid-19 period as seen in Chart 5.7. Therefore, the difference between consumer spending and age groups is $\% 5$ (p:0,000) meaningful and it changes according to age.

H4de: The hypothesis that is 'Spending on fresh, organic food, vitamin and mineral differs according to age' has been accepted. In other words, spending behaviors on fresh, organic food, vitamin and mineral differ according to age among the participants.

H4df: The hypothesis that is 'Spending on entertainment/travel/holiday and mass transportation differs according to age' has been accepted. There are differences in spending on entertainment/travel/holiday and mass transportation among the participants according to age.

H4dg: The hypothesis that is 'Spending on clothing differs according to age' has been rejected.\%1 statistically meaningful relation hasn't been found between spending on clothing and age group. According to the study, spending on clothing doesn't change according to age among the consumers.

H4dk: The hypothesis that is 'Spending on electronic differs according to age' has been accepted. There are differences in behavior of spending on electronic among the participants according to age. H4dl: The hypothesis that is 'Spending on house furniture and decoration differs according to age' has been rejected. \%1 statistically meaningful relation hasn't been found between spending on house furniture and decoration and age groups. According to the study, spending on house furniture and decoration doesn't change according to age among the consumers.

Table 5b: F Test (spending-2, continuous)

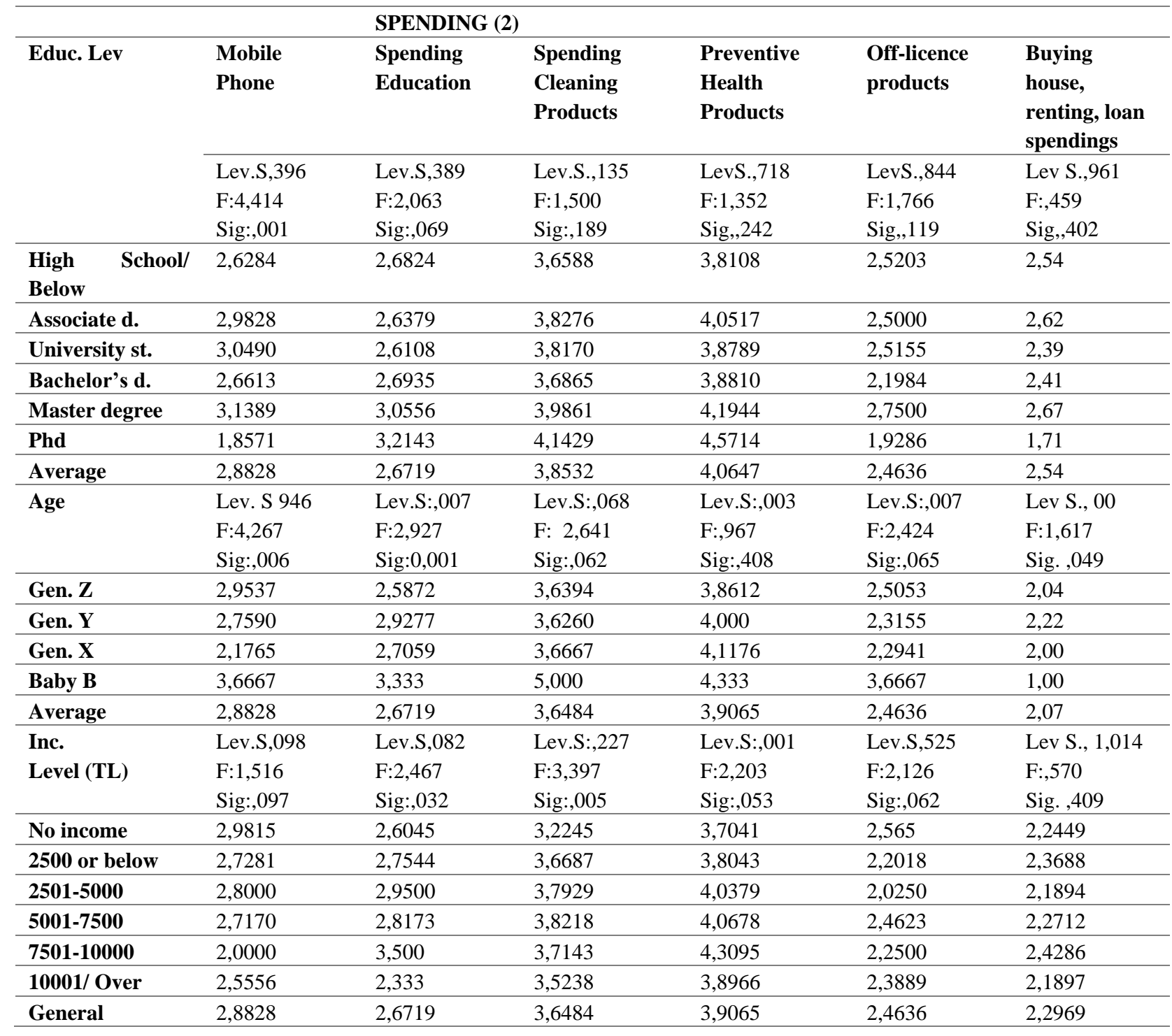


H4bb: The hypothesis that is 'Spending on off-licence products differs according to income variable' has been rejected. \%1 statistically meaningful relation hasn't been found between off-license products and income groups. According to the study, spending on off-license products doesn’t change according to income groups among the consumers.

H4bf: The hypothesis that is 'Spending on education differs according to income' has been accepted. In other words, there are differences in educational spending among the consumers according to income variable. It is seen that the income group spending on education most is the one between 7501-10000 TL.

H4bg: The hypothesis that is 'Spending on mobile phone differs according to income' has been rejected. \%1 statistically meaningful relation hasn't been found between mobile phone and income groups. In the study, there is no difference in spending on mobile phone according to income groups among the consumers.

H4bl: The hypothesis that is 'Buying house, renting and loan spending differ according to income 'has been rejected. \%1 statistically meaningful relation hasn't been found between buying house, renting and loan spending and income groups. In the study, spending on buying house, renting and loan don't differ according to income groups among the consumers.

H4bm: The hypothesis that is 'Spending on cleaning products differs according to income' has been accepted. In other words, there are differences in spending on cleaning products among the consumers in different income groups.

H4bn: The hypothesis that is 'Spending on preventive health products differs according to income' has been accepted. In other words, spending on preventive health products differs among the consumers in different income groups. It is seen that the income group spending on preventive health products most is the one between 7501-10000 TL.

H4cc: The hypothesis that is 'Spending on off-license products differs according to education level' has been rejected. \%1 statistically meaningful relation hasn't been found between spending on off-licence products and education levels. In the study, spending on offlicence products doesn't differ according to income groups among the consumers.

$\mathrm{H} 4 \mathrm{cg}$ : The hypothesis that is spending on education differs according to education level' has been rejected. The means of educational spending and education level have increased in favor of education level but a $\% 1$ meaningful relation hasn't been found. According to the study, there isn't a relation between educational spending and education level among the consumers.

H4ch: The hypothesis that is 'Spending on mobile phone differs according to education variable' has been accepted. It is seen that the education level spending on mobile phone least is the one with $\mathrm{PhD}$ degree.

$\mathrm{H} 4 \mathrm{cl}$ : The hypothesis that is 'Buying house, renting, loan spending differ according to education variable' has been rejected. \%1 statistically meaningful relation hasn't been found between buying house, renting, loan spending and education levels. According to the study, there isn't a relation between buying house, renting, and loan spending and education level among the consumers.

$\mathrm{H} 4 \mathrm{~cm}$ : The hypothesis that is 'Spending on cleaning products differs according to education level' has been rejected. \%1 statistically meaningful relation hasn't been found between spending on cleaning products and education levels. According to the study, there isn't a relation between spending on cleaning products and education levels among the consumers.

H4cn: The hypothesis that is 'Spending on preventive health products differs according to education variable' has been rejected. \%1 statistically meaningful relation hasn't been found between spending on preventive health products and education levels. According to the study, there isn't a relation between spending on preventive health products and education levels among the consumers.

H4dd: The hypothesis that is 'Spending on off-license products differs according to age' has been rejected. \%1 statistically meaningful relation hasn't been found between spending on off-license products and age groups. According to the study, spending on off-license products doesn't show difference according to age among the consumers.

H4dh: The hypothesis that is 'Spending on education differs according to age' has been accepted. There are differences in educational spending according to age among the participants.

H4di: The hypothesis that is 'Spending on mobile phone differs according to age' has been accepted. There are differences in spending on mobile phone according to age among the participants. It is seen that the mean of the group spending on mobile phone least is 3,6667 (Baby Boomers).

H4dm: The hypothesis that is 'Buying house, renting, loan spending differ according to age' has been accepted. Buying house, renting, loan spending differ according to age among the participants.

H4dn: The hypothesis that is 'Spending on cleaning products differs according to age' has been rejected. \%1 statistically meaningful relation hasn't been found between spending on cleaning products and age groups. According to the study, there isn't a relation between spending on cleaning products and age among the consumers.

H4dp: The hypothesis that is 'Spending on preventive health products differs according to age' has been rejected. \%1 statistically meaningful relation hasn't been found between spending on preventive health products and age groups. According to the study, spending on preventive health products differ according to age among the consumers 
Table 5c: F Test (saving)

\begin{tabular}{|c|c|c|c|c|c|c|c|}
\hline & SAVING & & & & & & \\
\hline & & Mean & df & $\begin{array}{l}\text { Mean } \\
\text { Sq. }\end{array}$ & $\begin{array}{l}\text { Lev. } \\
\text { Sig. }\end{array}$ & $\mathrm{F}$ & Sig. \\
\hline \multirow{7}{*}{$\begin{array}{l}\text { Edu. } \\
\text { Level }\end{array}$} & Between Groups & Master degree: 3,0370 & 5 & 1,944 & \multirow[t]{7}{*}{,307 } & \multirow[t]{7}{*}{2,855} & \multirow[t]{7}{*}{, 015} \\
\hline & Within Groups & Associate dg. : 3,0920 & 379 & 681 & & & \\
\hline & Total & 3,1905(Bachelor's d.) & 384 & & & & \\
\hline & & 3,2117 (High school or below) & & & & & \\
\hline & & 3,4639(Unv.Std.) & & & & & \\
\hline & & 3,6667(Phd) & & & & & \\
\hline & General Average & 3,3264 & & & & & \\
\hline \multirow[t]{5}{*}{ Age } & Between Groups & 3,3962 (Gen. Z) & 3 & 2,049 & \multirow[t]{5}{*}{,097 } & \multirow[t]{5}{*}{2,984} & \multirow[t]{5}{*}{, 031} \\
\hline & Within Groups & 3,1429 (Gen. Y) & 381 & 687 & & & \\
\hline & Total & 3,0196 (Gen. X) & 384 & & & & \\
\hline & & 3,6667 (Baby B) & & & & & \\
\hline & General Average & 3,3264 & & & & & \\
\hline \multirow{7}{*}{$\begin{array}{l}\text { Income } \\
\text { Level }\end{array}$} & Between Groups & $3,00(5001-7500 \mathrm{TL})$ & 5 & 2,566 & \multirow[t]{7}{*}{,634 } & \multirow[t]{7}{*}{3,815} & \multirow[t]{7}{*}{, 002} \\
\hline & Within Groups & $3,00(10001 \mathrm{TL} / \mathrm{Over})$ & 379 & 673 & & & \\
\hline & Total & $3,1404(2500$ or below) & 384 & & & & \\
\hline & & $3,1667(75001-10000 \mathrm{TL})$ & & & & & \\
\hline & & 3,4317 (No income) & & & & & \\
\hline & & $3,600(2501-5000 \mathrm{TL})$ & & & & & \\
\hline & General Average & 3,3264 & & & & & \\
\hline
\end{tabular}

Table 5d: F Test (fear)

\begin{tabular}{|c|c|c|}
\hline \multirow[b]{3}{*}{ Education Lev } & \multicolumn{2}{|l|}{ Fear } \\
\hline & Fear of the virus & Fear of Activity \\
\hline & Lev.S:2,818F:1,365 Sig:0,02 & Lev.S:,1,109 F:2,832 Sig:,043 \\
\hline High school or below & 3,8919 & 3,6564 \\
\hline Associate degree & 4,0116 & 3,8074 \\
\hline University student & 3,5948 & 3,6032 \\
\hline Bachelor's degree & 3,9444 & 3,8912 \\
\hline Master degree & 4,0556 & 4,0278 \\
\hline Phd & 4,0357 & 4,0102 \\
\hline General Average & 3,9487 & 3,7805 \\
\hline Age & Lev.S., 1,294 F:1,212 Sig:,030 & Lev.S:5,498: F:3,308 Sig:,020 \\
\hline Gen Z (18-25) & 3,7457 & 3,50 \\
\hline Gen Y $(26-40)$ & 3,9524 & 3,88 \\
\hline Gen X (41-54) & 3,8235 & 3,58 \\
\hline Baby B(55+) & 4,8333 & 4,58 \\
\hline General Average & 3,9487 & 3,59 \\
\hline Income Level (TL) & Lev.S:1,264 F:2,486 Sig:0,03 & Lev.S:,1,109 F:2,832 Sig:,016 \\
\hline No income & 4,0297 & 3,8278 \\
\hline 2500 or below & 3,8288 & 3,7719 \\
\hline $2501-5000$ & 3,9250 & 3,7286 \\
\hline $5001-7500$ & 3,7783 & 3,8423 \\
\hline $7501-10000$ & 4,8750 & 4,1786 \\
\hline 10001/ Over & 3,3611 & 2,6508 \\
\hline General Average & 3,9487 & 3,7907 \\
\hline
\end{tabular}

H5: The hypothesis that is 'Consumer savings differ according to demographic changes' has been accepted. As seen in Table 5.9, there is statistical difference between consumer saving, education level, age and income groups during the Covid-19 period. In this 
study, there is statistically meaningful difference between consumer saving-education at the level of $\% 1$ (p:0,015), between saving and age $\% 1$ (p:0,031), and saving and income $\% 5$ (p:0,002). Therefore, saving behavior changes according to demographic features.

H5b: The hypothesis that is 'Consumer saving differs according to income' has been accepted. In other words, there is difference in saving rate according to income variable among the participants.

H5c: The hypothesis that is 'Consumer saving differs according to education level' has been accepted. There is difference in consumer saving behavior according to education level among the participants.

H5d: The hypothesis that is 'Consumer saving differs according to age' has been accepted. There are differences in consumer saving rates among the participants according to age variable. It is seen that the group saving the most according to age groups in terms of consumer saving is baby boomers while the group having the least mean is Generation X. In summary, the hypotheses of H5, H5b, H5d have been accepted.

H6b: The hypothesis that is 'Fear of the virus differs according to income variable' has been accepted. In other words, there is difference in fear of the virus among the participants according to income variable.

H6c: The hypothesis that is 'Fear of the virus differs according to education variable' has been accepted. Fear of the virus changes according to education level among the participants.

H6d: The hypothesis that is 'Fear of the virus differs according to age' has been accepted. There are differences in fear of the virus according to age variable among the participants.

H6f: The hypothesis that is 'Fear of activity differs according to income' has been accepted. In other words, there are differences regarding the fear of the virus among the participants according to income variable.,

H6g: The hypothesis that is 'Fear of the virus differs according to education variable' has been accepted. Fear of the virus changes according to education level among the participants.

H6h: The hypothesis that is 'Fear of activity differs according to age variable' has been accepted. There are differences among the participants regarding fear of activity according to age variable.

Table 5e: F Test (all of variable)

\begin{tabular}{|c|c|c|c|c|c|c|}
\hline \multicolumn{7}{|l|}{ ANOVA } \\
\hline Model & & Sum of Squares & $\mathrm{df}$ & Mean Square & $\mathrm{F}$ & Sig. \\
\hline \multirow[t]{3}{*}{ Fear of virus } & Regression & 257,311 & 28 & 9,190 & 111,459 & 000 \\
\hline & Residual & 29,352 & 356 & ,082 & & \\
\hline & Total & 286,662 & 384 & & & \\
\hline \multirow[t]{3}{*}{ Fear of Activity } & Regression & 170,696 & 28 & 6,096 & 7,014 & , 000 \\
\hline & Residual & 309,412 & 356 & ,869 & & \\
\hline & Total & 480,108 & 384 & & & \\
\hline \multirow[t]{3}{*}{ Saving } & Regression & 52,475 & 28 & 1,874 & 1,491 & , 045 \\
\hline & Residual & 446,147 & 355 & 1,257 & & \\
\hline & Total & 498,622 & 383 & & & \\
\hline \multirow[t]{3}{*}{ Spending } & Regression & 14,796 & 28 & ,528 & 1,827 & ,007 \\
\hline & Residual & 102,969 & 356 & ,289 & & \\
\hline & Total & 117,766 & 384 & & & \\
\hline
\end{tabular}

a. Dependent variables: Fear b. Predictors: (Constant), Saving, Spending

The total of $\mathrm{F}_{\text {count }}$ in this research is as follows: The above table shows that the fear value of $\mathrm{F}_{\text {count }}$ is 111,459 , fear of activity value of $F_{\text {count }}$ is 7,014, saving value of $F_{\text {count }}$ is 1,491, spending value of $F_{\text {count }}$ is 1,827 and all of with probability 0,000 . Since its probability is smaller than 0.05 and then Ho is rejected or Ha is accepted which means that variables of saving, spending, fear of virus and fear of activity have a significant effect on on customer behavior.

\section{Multiple Linear Regression Analysis}

Below is the table of the results of the processed 
Table 6: Multiple Linear Regression Test Results Coefficients

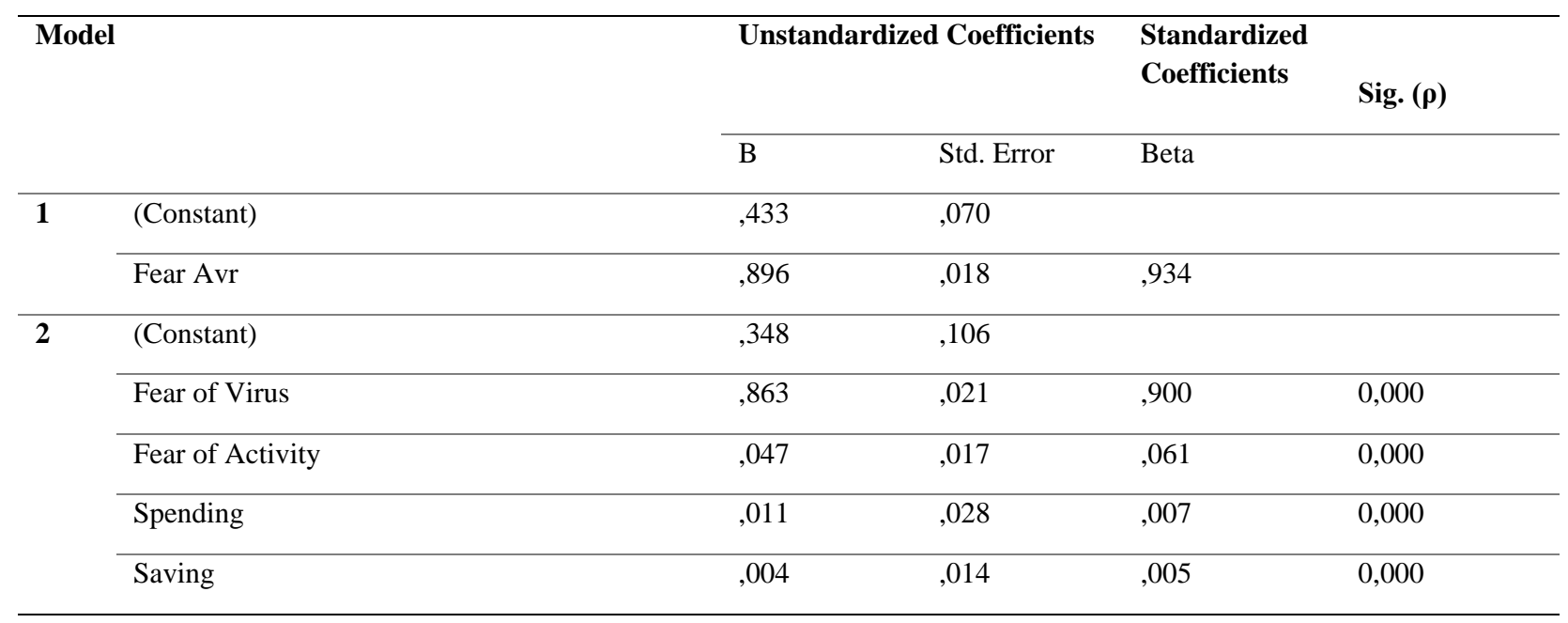

Note: Dependent Variables: Consumer Behavior

Data for multiple linear regression test of these variables: The regression equation formed from the data on the above table is as follows:

$Y=0,348-0,863 X 1+0,47 X 2+0,11 X 3+0,004 X 4+e$

The above equation leads to the following results:

- Constanta (a) =0,348 which means fear of virus that although the independent variable (X1) ; fear of activity and independent variable $\mathrm{X} 2$, : spending, the independent variable; $\mathrm{X} 3$, saving the independent variable $\mathrm{X} 3$; spending independent variable $\mathrm{X} 4$, then consumer behavior (Y) remains to be 0,348 .

- Coefficient X1 (b1) = 0.863 and positive value. This means that each fear of virus variable improvement by 1 leads to the increased consumer behavior (Y) by 0.863 .

- Coefficient X2 (b2) = 0,47 and positive value. This means that each fear of activity variable improvement by 1 leads to the increased consumer behavior (Y) by 0,47

- Coefficient X3 (b3) $=0.11$ and positive value. This means that each spending variable improvement by 1 leads to the increased consumer behavior (Y) by 0,11

- Coefficient X4 (b3) = 0.04 and positive value. This means that each saving style variable improvement by 1 leads to the increased consumer behavior (Y) by 0,04

Based on the processed data above, it is revealed that the variable with the most dominant effect on job consumer behavior is fear of virus as its coefficient regression value is bigger than other independent variables.

\section{Coefficient of Determination}

Coefficient of Determination is obtained with the help of SPSS Program:

Table 7: Coefficient of Determination Coefficients

\begin{tabular}{lllll}
\hline Model & $\mathbf{R}$ & R Square & Adjusted R Square & Std. Error of the Estimate \\
\hline $\mathbf{1}$ &, $934^{\mathrm{a}}$ &, 872 &, 872 &, 310 \\
\hline $\mathbf{2}$ &, $935^{\mathrm{b}}$ &, 875 &, 873 &, 307 \\
\hline
\end{tabular}

Note: Dependent Variables: Consumer Behavior

The value of coefficient of determination (R Square) revealed that consumer behavior during Covid-19 pandemic mutually influenced by an fear of virus, fear of activity, spending and saving by 0,875 or $88 \%$ while the remaining $12 \%$ is influenced by other factors beyond the scope of this research. Since its probability is smaller than 0.05 and the hypothesis are accepted which means that the variables of an fear of virus, fear of activity, spending and saving have a significant effect on consumer behavior during Covid-19 epidemic. The multiple linear regression equation formed is $Y=0,348-0,863 X 1+0,47 X 2+0,11 X 3+0,004 X 4+e$. From this equation, it can be seen that the variable is a variable of fear of virus variable as its coefficient regression is bigger than other independent variables. The extent of the influence can be seen from the coefficient of determination value. The value of coefficient of determination (R Square) showed that consumer behavior during Covid-19 epidemic simultaneously influenced by , fear of activity, spending and saving by $88 \%$ while the remaining $12 \%$ is influenced by other factors beyond the scope of this research. The results of the study showed that, simultaneously, an fear of virus, fear of activity, spending and saving have significant effects on 
consumer behavior during Covid-19 in Turkey and partially the variable of fear of virus is more dominant than other three independent variables

\section{Conclusions}

In this study, the relation between the fear of (the virus and activity), spending (cleaning products, protective health products, fresh and organic food together with vitamin/mineral support, off-license products, clothing, education, buying house, car, taking loan, renting, holiday, travel, entertainment, electronic, house decoration/furniture, mobile phone) and saving has been tested.

The participants are mostly afraid of being infected by the Covid-19 virus (\%75); they believe that the worst effects of the virus will be seen later and the world is under a serious threat due to the Covid-19 pandemic and they expect an economic recession;

i. $\quad$ they changed their daily life; they increased their spending in the last three months (February, March, April, 2020) but they decreased their daily spending for now; they plan to spend less on general spending, luxurious products and fashion products in the next 6 months (June-November 2020);

ii. $\quad$ they don't believe economy will be better in the next 12 months (May 2020-May 2021)

iii. they don't have a plan about future spending yet; they are afraid of travelling internationally, domestic flight, voyage, travelling by bus, tram or train, staying at a hotel, taking a taxi, going to restaurants, entertainment places and stores, doing shopping except online shopping and finally they have increased their savings due to the pandemic.

Additionally, the Covid-19 process has been examined according to gender and it has been noticed that during the process women have spent on cleaning products on fresh/organic food/vitamin/mineral more than men; and also they have more general fear of the virus and fear of activity (international travel, domestic flight, travel by sea, air and land, staying a hotel, taking a taxi, going shopping, going to restaurant) than men. At this point, businesses can target women consumers more and create strategic marketing tactics and overcome this difficult process more easily.

Generally the rate of consumers 'saving has increased especially at high income level.

Spending on fresh/organic food \& mineral differs according to the variables of income, education and age.

It has been noticed that spending of those with no income at all and those with more than 10000TL on fresh/organic food \& vitamin/mineral has mostly remained the same simply because consumers with low income level has no potential of spending and those with high income level are already able to spend enough even before Covid-19.

The fact that the group that saves the most and the group that buys the most fresh fruits and vegetables is Baby Boomers(55+) is thought to be due to the fact that this generation is the post-war generation and that it is due to the high famine awareness and being old who were born after the war (WWII). Also; this is maybe because while Generation Z thinks they will not be affected by the Covid-19 virus and Baby Boomers are in the age group that is expected to be affected most.

It has been noticed that the group that has the least mean of saving is Generation X (41-54). This can be based on the fact that they are still in work life and a mature age range, so they have the potential to exhibit calmer behaviors.

It has been determined that according to education level, the saving behavior and spending on fresh/organic food, vitamin-mineral rate of those with Phd degree is higher than that of other education levels and also that of the average.

Spending on entertainment/travel/holiday and mass transportation has decreased among the generations. Generation $\mathrm{Z}$ has been the one that has spent most travel and on electronic equipment and mobile phone while Baby Boomers have been the one that has spent least for traveling and the one most spending on electronic equipment and mobile phone.

In the study, spending on electronic equipment and mobile phone doesn't differ according to income and interestingly it shows a picture independent from income.

The average electronic spending of consumers has decreased a little. While consumers in Generation X (18-25) is the one that has made the most spending, oppositely Baby Boomers (55+) have become the one that have made the most spending on mobile phone. Generation X (41-54) has decreased their mobile phone spending and Generation Z (18-25) hasn't performed an important change in their saving habit.

It has been noticed that educational spending of the consumers doesn't differ according to education level and they are stuck between decreasing their educational spending or keeping it stable but the general tendency shows that spending on education has been decreased.

The income group performing the most spending on cleaning products is the one between 5001-7500TL, but the income group performing the most spending on preventive health products is the one between 7501-10000TL. While the group with lower income has prioritized reactive products such as cleaning products, the group with higher income has prioritized proactive products such as preventive health products. This case proofs Maslow's hierarchy of needs in that people can advance to the next stage after the basic needs as their income increases; otherwise, they stay at the same stage unsuccessfully. 
Spending on cleaning products and preventive health products didn't change according to education level and age, which means that the society spent money according to their income regardless of their education level and age range.

It has been found that consumption of off-license products has generally decreased regarding consumer spending and this kind of spending hasn't changed according to income, education level and age by exhibiting similar spending behavior. While spending on buying house, renting, loan hasn't differed according to income level and education level, it has differed according to generation and decline in spending has been mostly seen in Baby Boomers group.

The consumers with no income at all have become the second regarding the fear of the virus. The fact that the group, which is afraid of the virus most and which has the most fear of activity, is the same can be an indicator that income has caused multiplier effect.

It is seen that the group that has fear of activity and the virus most is Baby Boomers (55+) while the group that has the least fear of the virus is Generation Z (18-25). It is thought that the reason of the fear of Baby Boomers is their consciousness about having higher risks in terms of health. It is thought that the consumers with postgraduate degrees might have improved their result evaluating and analytic thinking skills in parallel with their higher level of knowledge and education and therefore feeling more afraid and concerned in comparison to the other education levels. This can be made the research topic of a different study.

\section{References}

Arora, N., Pflumm, S. Rodriguez, L., Robinson, K., Bhargav, S., Tamara, R.D., Rishi, A., Grimmelt, A., Sexauer, C. \& Tormo, S. (2020). Survey: US consumer sentiment during the coronavirus crisis. Retrieved from https://www.mckinsey.com/businessfunctions/marketing-and-sales/our-insights/survey-us-consumer-sentiment-during-the-coronavirus-crisis

Arthur, S. \& Henry, M. (2020, April). Tüketici İçgörüleri. Belirsizlik zamanlarında tüketiciler finansal durumlarını nasıl koruyor? Retrieved from https://www.thinkwithgoogle.com/intl/tr-tr/icgoruler/tuketici-trendleri/belirsizlik-zamanlarinda-tuketicilerfinansal-durumlarini-nasil-koruyor/

Aytekin, M. \& Ekinci, G. (2014). Demographic characteristics of consumer buying behavior effects of environmentally friendly products and an application in Gaziantep. The Business \& Management Review,5(1), 72-82

Bacquet, P.F., Gilavert, M. \& Hequet-Cotin, C. (Dec 11, 2020). Survey: French consumer sentiment during the coronavirus crisis. Retrieved from https://www.mckinsey.com/business-functions/marketing-and-sales/our-insights/survey-french-consumersentiment-during-the-coronavirus-

crisis\#: :text=Survey\%3A\%20French\%20consumer\%20sentiment\%20during\%20the $\% 20$ coronavirus $\% 20$ crisis,-

December\%2011\%2C\%202020\&text=As\%20France\%20goes\%20through\%20its, in\%20the\%20spring\%20of\%202020.

Bagozzi, R.P., Gurhan-Canli, Z. \& Priester, J. R. (2002). The Social Psychology of Consumer Behaviour. Buckingham: Open University Press.

BBC (2020a, April, 28). Koronavirüs salgını tüketici alışkanlıklarını nasıl değiştiriyor? Retrieved from https://www.bbc.com/turkce/haberler-dunya-52448919

BEA (Bureau of Economic Analysis) (2020a). Personal Saving Rate. Retrieved from https://www.bea.gov/data/incomesaving/personal-saving-rate

BEA (2020b). Disposable Personal Income Retrieved from https://www.bea.gov/data/income-saving/disposable-personal-income

Bendau, A., Petzold, M.B., Pyrkosch, L., Maricic, LM., Betzler, F., Große, J., Ströhle, A. \& Plag, J. (2020). Associations between COVID-19 related media consumption and symptoms of anxiety, depression and COVID-19 related fear in the general population in Germany. Eur Arch Psychiatry Clin Neurosci. 1-9 . doi:10.1007 / s00406-020-01171-6

Bland, P. (2020). Supporting Brands' Response Enabling Recovery and Returning To Growth Amids Covid-19 (Coronavirus). Retrieved from https://www.iprospect.com/en/gb/news-and-views/insights/response-recovery-and-return-to-growth-amidstcovid-19-11-may-2020/

Bland, P., Williams, M., Verschuren, R., Dimond, D. \& Newman, D. (2020) Tracking Consumer Behaviour Change Amidst COVID19 (Coronavirus). iPROSPECT Retrieved from https://www.iprospect.com/en/gb/news-and-views/insights/trackingconsumer-behaviour-amidst-covid-19-27-march-2020/

Blanchard, C. M., Kupperman, J., Sparling, P. B., Nehl, E., Rhodes, R. E., Courneya, K. S., \& Baker, F. (2009). Do ethnicity and gender matter when using the theory of planned behavior to understand fruit and vegetable consumption? Appetite, 52(1), $15-20$.

Boata, A., Holzhausen \& A., Subran, L. (2020). Europe Should Unlock Excess Savings From Covid-19 Response, 22 April 2020. Allianz Research. Retrieved from https://www.eulerhermes.com/content/dam/onemarketing/ehndbx/eulerhermes_com/en_gl/erd/publications/thewatch/2020_04_22Covidexcesssavings-final.pdf

Botti, S. \& McGill, A. L., (2011). The Locus of Choice: Personal Causality and Satisfaction with Hedonic and Utilitarian Decisions. Journal of Consumer Research. 37 (6), 1065-78.

Bray, J. (2008). Consumer Behaviour Theory: Approaches and Models. Discussion Paper. Unpublished. (Unpublished). pp. 1-33. http://eprints.bournemouth.ac.uk/10107/1/Consumer_Behaviour_Theory_-_Approaches_\%26_Models.pdf

Brown, J.H. \& Oplatka, I. (2016). Introduction to Higher Education Consumer Behaviour. Higher Education Consumer Choice doi: 10.1007/978-1-137-49720-8_1 
Castillo, J. Marcos, I., Omeñaca, J., Ortega, M., Carlos, S. A. \& Staack, Y. (2020, December 14). Survey: Spanish consumer sentiment during the coronavirus crisis. Retrieved from https://www.mckinsey.com/business-functions/marketing-and-sales/ourinsights/survey-spanish-consumer-sentiment-during-the-coronavirus-crisis

Catena, M., Longo, R., Romeo, R., Samiani, M. \& Zizioli, M. (2020). Italian Consumers' Optimism About An Economic Recovery Has Held Fairly Steady, Even As Restrictions Have Started To Loosen. Research Survey. McKinsey\& Company Website. https://www.mckinsey.com/business-functions/marketing-and-sales/our-insights/survey-italian-consumer-sentimentduring-the-coronavirus-crisis

Child, J., Smith, T.R. \& Tesviç, J. (2020). Survey: Australian consumer sentiment during the coronavirus crisis. Research Survey. McKinsey\& Company Website https://www.mckinsey.com/business-functions/marketing-and-sales/our-insights/surveyaustralian-consumer-sentiment-during-the-coronavirus-crisis

Cialdini, R. (2006) The psychology of Persuasion. Publisher: New York :HarperCollins e-books. Retrieved from http://elibrary.bsu.az/books_400/N_232.pdf

Cranfield J. (2020). Framing consumer food demand responses in a viral pandemic.Canadian Journal of Agricultural Economics/Revue canadienne d'agroeconomie, 10.1111/cjag.12246. doi:/10.1111/cjag.12246

Chronopoulos, D.K., Lukas, M. \& Wilson, J.O.S. (2020). Consumer Spending Responses to the COVID-19 Pandemic: An Assessment of Great Britain. ERC Res. Pap. Covid Economics, 145 - 186. Retrieved from https://scholar.google.com/citations?user=gchHO1QAAAAJ\&hl=en

Duhachek, A. \& Kelting, K. (2009). Coping Repertoire: Integrating a New Conceptualization of Coping with Transactional Theory, Journal of Consumer Psychology, 19 (3), 473-85.

Durante, K.M. \& Laran, J. (2016). The Effect of Stress on Consumer Saving and Spending, Journal of Marketing Research. 1-56. https://journals.sagepub.com/doi/10.1509/jmr.15.0319

EST, Eurostat Statistics Explained (2020). Impact of Covid-19 crisis on non-financial corporation and household accounts. Retrieved from https://ec.europa.eu/eurostat/statistics-explained/index.php?title=Impact_of_Covid-19_crisis_on_nonfinancial_corporation_and_household_accounts\&stable=0\&redirect=no\#Household_gross_disposable_income.2C_saving_ and_investment_rates).

Euromonitor (2020a). The Impact of Coronavirus on Top 10 Global Consumer. Retrieved from https://www.euromonitor.com/theimpact-of-coronavirus-on-top-10-global-consumer-trends-2020/report 08.08.2020

Fish, D. (2020). Heroes and Zeroes: How Organizations are Treating Customers and Employees During the COVID-19 Pandemic. Retrieved from https://customerthink.com/heroes-and-zeroes-how-organizations-are-treating-customers-and-employeesduring-the-covid-19-pandemic/

Foroughi, A., Buang, N. A., Che Senik, Z., \& Sadat Hajmisadeghi, R. (2013). Impulse buying Behaviour and Moderating role of gender among Iranian Shoppers. Journal of Basic and Applied Scientific Research, 3(4), 760-769.

Genç, S. (2020). Covid-19 Tüketiciler Ne İstiyor? Markalar Ne Yapıyor? Retrieved from https://hbrturkiye.com/blog/covid-19tuketiciler-ne-istiyor-markalar-ne-yapiyor

Girod, S.J. G. (2020). Five New Trends That Will Reshape Luxury After COVID-19. Retrieved from https://www.forbes.com/sites/stephanegirod/2020/04/19/five-inflection-points-that-will-reshape-luxury-with-covid19/\#70d8b75e4eb1

Giugliano, F. (2020, April 08). Italy Has More to Fear Than the Coronavirus. Bloomberg Retrieved from https://www.bloombergquint.com/gadfly/coronavirus-italy-has-more-to-fear-than-covid-19.

Greer, G. (2020). Survive to Thrive Data Blog Series: Consumer Saving During COVID-19 and the PFM Opportunity. Retrieved from https://www.celent.com/insights/131256862

Grimmelt, A., Hattingh, D. \& Ramlaken, S. (2020a). Survey: South African consumer sentiment during the coronavirus crisis. McKinsey \& Company. Retrieved from https https://www.mckinsey.com/business-functions/marketing-and-sales/ourinsights/survey-south-african-consumer-sentiment-during-the-coronavirus-crisis

Grimmelt, A., Mckinsey Stamford; Iftahy,A., Mellens, M. \&Youssef, A. (2020b). Survey: Saudi consumer sentiment during the coronavirus crisis. McKinsey \& Company. Retrieved from https https://www.mckinsey.com/business-functions/marketingand-sales/our-insights/survey-saudi-consumer-sentiment-during-the

Gunday, G., Kiladze, K. \& Staack, Y. (2020). Survey: UK consumer sentiment during the coronavirus crisis. McKinsey \& Company. Retrieved from https://www.mckinsey.com/business-functions/marketing-and-sales/our-insights/survey-uk-consumersentiment-during-the-coronavirus-crisis 28.07.2020

GWI (GlobalWebIndex). Coronavirus Research :| April 2020 Multi-Market Research Wave 3 Retrieved from https://www.globalwebindex.com/hubfs/1.\%20Coronavirus\%20Research\%20PDFs/GWI\%20coronavirus\%20findings\%20 April\%202020\%20-\%20Multi-market\%20research\%20(Release\%209).pdf

Harvard Business School (2020). Global Behaviors and Perceptions at the Onset of the COVID-19 Pandemic. Working Knowledge Business Research for Business Leaders. Retrieved from https://hbswk.hbs.edu/item/global-behaviors-and-perceptions-atthe-onset-of-the-covid-19-pandemic?cid=spmailing-32210723-WK\%20Newsletter\%2005-20-2020\%20(1)-

May\%2020,\%202020 
Harvey, J., Erdos, G., Challinor, S., Drew, S., Taylor, S., Ash, R., Ward, S., Gibson, C., Scarr, C., Dixon, F. \& Hinde, A. (2001). The relationship between attitudes, demographic factors and perceived consumption of meats and other proteins in relation to the BSE crisis: a regional study in the United Kingdom. Health, Risk \& Society, 3(2), 181-197.

Ho, J., Zhang, C., Kim, A., Lerkriangkraisorn, V. \& Wu, O. (2020). Survey: Chinese consumer sentiment during the coronavirus crisis. McKinsey \& Company. Retrieved from https://www.mckinsey.com/business-functions/marketing-and-sales/ourinsights/survey-chinese-consumer-sentiment-during-the-coronavirus-crisis

Hoyt, C. (2010). Touching the elephant, Markus, S. and Maila, V. (Eds), Shopper Marketing: How to Increase Purchase Decisions at the Point of Sale. (2nd Edition, pp. 161-168) London: Kogan Page Publishers.

Işın, F. B. (2020a, May 04) Koronavirüs Salgınında Tüketici Eğilimleri Retrieved from http://feridebaharisin.com/koronavirussalgininda-tuketici-egilimleri-kobi-aktuel/

Kahneman, D. ve Tversky, A. (1979). Prospect Theory: Decision Making Under Risk. Econometrica, (47),2: $263-292$. doi:10.2307/1914185

Kikuchi, S., Kitao S. \& Mikoshiba, M. (2020). Heterogeneous Vulnerability to the COVID-19 Crisis and Implications for Inequality in Japan. Research Institute of Economy, Trade and Industry (RIETI): Discussion papers 20039, Research Institute of Economy, Trade and Industry (RIETI).

Koslow, L., Lee, J., Bharadwaj, A., Sanghi, K. \& Barrios, G. (2020a) COVID-19 Consumer Sentiment Snapshot \#5: A Story for the Ages. BCG. Retrieved from https://www.bcg.com/publications/2020/covid-consumer-sentiment-survey-snapshot-4-1320.aspx

Koslow, L., Lee, J., Tsusaka, M. Bharadwaj, A., Wegner, M. Sanghi, K. \& Jain, N. (2020b, May 06). COVID-19 Consumer Sentiment Snapshot: Special Feature-Asia-Pacific A (More) Digital World. BCG Retrieved from https://www.bcg.com/publications/2020/covid19-consumer-sentiment-special-feature-asia-pacific.aspx

Kotler, P., \& Armstrong, G. (2018). Principles of Marketing (17 ed.). Harlow: Pearson Education

Leone, L., Perugini, M. Ercolani, A. P. 2004. Studying, Practicing, and Mastering: A Test of the Model of Goal-Directed Behavior in the Software Learning Domain. Journal of applied social psychology. 34 (9), 1945-1973.

Lidwell, W., Holden, K. \& Butler, J. (2006). Universal Principles of Design, Revised and Updated: 125 Ways to Enhance Usability, Influence Perception, Increase Appeal, Make Better Design Decisions, and Teach through Design Retrieved from https://books.google.com.tr/books?id=10QPECGQySYC\&pg=PA216\&lpg=PA216\&dq=Robert+Cialdini+limited+access+p rinciple\&source=bl\&ots=_P591fBbEu\&sig=ACfU3U2iPTVqn1ABkX61wLZEbEu3Erq0SQ\&hl=tr\&sa=X\&ved=2ahUKEw jkhaO1-

7PqAhV0wuYKHbjOBnQQ6AEwDnoECAgQAQ\#v=onepage\&q=Robert\%20Cialdini\%20limited\%20access\%20principle $\% 20$ cialdini\&f $=$ false

Mansoor, D. and Jalal, A. (2011). The Global Business Crisis and Consumer Behaviour: Kingdom of Bahrain as a Case Study. International Journal of Business and Management, 6(1), 104-115

Meyer, S. (2020). Understanding the COVID-19 Effect on Online Shopping Behavior Retrieved from https://www.bigcommerce.com/blog/covid-19-ecommerce/\#understanding-panic-buying-and-coronavirus

Nicola, M., Alsafi, Z., Sohrabi, C., Kerwan, A. Iosifidis, C. Agha \& Agha, R. (2020). The socio-economic implications of the coronavirus pandemic (COVID-19): A review International Journal of Surgery, 78(7), 185-193 doi: 10.1016/j.jisu.2020.04.018

McMullan, L., Duncan, P., Hulley-Jones, F. \& Blight, G. (2020, July 22). he psychological toll of coronavirus in Britain - a visual guide. The Guardian. Retrieved from https://www.theguardian.com/world/ng-interactive/2020/jul/22/psychological-tollcoronavirus-britain-visual-guide-anxiety-mental-strain 07.08.2020

Numerator Intelligence (2020a, April 02). 4/2 Update: The Impact of Coronavirus (COVID-19) on Consumer Behavior Retrieved from https://www.numerator.com/resources/blog/update-impact-coronavirus-covid-19-consumer-behavior-us

Numerator Intelligence (2020b, May 14). 5-14 Update: The Impact of Coronavirus (COVID-19) on Consumer Behavior. Retrieved from https://www.numerator.com/resources/blog/update-impact-coronavirus-covid-19-consumer-behavior-us-9

OECD, (2020). OECD Economic Outlook, June 2020 The World Economy On A Tightrope Retrieved from https://www.oecd.org/economic-outlook/

Popper, R., Smits, G., Meiselman, H. L. \& Hirsch, E. (1989). Eating in Combat: A Survey of US Marines. Military Medicine, 154 (12), 619-23. doi:10.1093/milmed/154.12.619

Radu, V. (2019.) Consumer behavior- in marketing-patterns, types, segmentaion. Retrieved from https://www.omniconvert.com/blog/consumer-behavior-in-marketing-patterns-types-segmentation.html

Schmidt, J.K., Perrey, J., Leibbrand, J., Spillecke, D. \& Staack, Y. (2020, December 14). Survey: German consumer sentiment during the coronavirus crisis Retrieved from https://www.mckinsey.com/business-functions/marketing-and-sales/ourinsights/survey-german-consumer-sentiment-during-the-coronavirus-crisis 28.07.202

Sheth, J. (2020). Impact of Covid-19 on consumer behavior: Will the old habits return or die? Journal of Business Research, 117(2020) 280-283. doi.org/10.1016/j.jbusres.2020.05.059.

Singh, A.(2020, April 09). Consumer spending and consumption to be severely impacted by COVID-19 crisis. TheWeek. Retrieved from https://www.theweek.in/news/biz-tech/2020/04/09/consumer-spending-and-consumption-to-be-severely-impacted-bycovid-19-crisis.html 03.08.2020 
Sinha, S. (2020, Jun 01). Are indians spending less, saving more during covid-19 lockdown? Here's what SBI research reveals.Financial Express. Retrieved from https://search.proquest.com/newspapers/are-indians-spending-less-saving-moreduring/docview/2407982577/se-2?accountid=15958

Statista (2020). Number of confirmed coronavirus (COVID-19) cases in Spain between February 12 and July 29, 2020 Retrieved from https://www.statista.com/statistics/1107415/confirmed-coronavirus-cases-spain-march/

Statista (2020b). Confidence in organizations to handle the coronavirus (COVID-19) outbreak in France in 2020 Retrieved from https://www.statista.com/statistics/1103749/organizations-confidence-coronavirus-france/

Statista (2020c). Are you worried about the spread of the COVID-19 coronavirus in France? Retrieved from https://www.statista.com/statistics/1101013/worried-coronavirus-france/

Taylor, S. (2020, April 07). For the generation shaped by coronavirus, life may never fully return to 'normal'. The Guardian. Retrieved from https://www.theguardian.com/commentisfree/2020/apr/07/life-never-return-normal-coronavirus-shape-generation

Türkiye Ekonomi Politikaları Araştırma Vakfı TEPAV (2020a) COVID-19'un tüketici harcamalarına etkisi. Mart 2020 N202007 Retrieved from https://www.tepav.org.tr/upload/files/1585626661-9.COVID_19__un_tuketici_harcamalarina_etkisi.pdf

The Guardian (2020e, July 15). Revealed: Italy's call for urgent help was ignored as coronavirus swept through Europe Retrieved from https://www.theguardian.com/world/2020/jul/15/revealed-the-inside-story-of-europes-divided-coronavirus-response

Throop, A.W. (1992). Consumer Sentiment: Its Causes and E_ects. Economic Review, 1, 35-59.

Türkiye İstatistik Kurumu [TUIK] (2020). Konularına Göre İstatistikler Adrese Dayalı Nüfus Kayıt Sistemi Retrieved from http://www.tuik.gov.tr/PreTablo.do?alt_id=1059

World Health Organization [WHO] (2020d). WHO Coronavirus Disease (COVID-19) Dashboard. Retrieved from https://covid19.who.int/

Publisher's Note: SSBFNET stays neutral with regard to jurisdictional claims in published maps and institutional affiliations.

\section{(1) (1)}

(C) 2021 by the authors. Licensee SSBFNET, Istanbul, Turkey. This article is an open access article distributed under the terms and conditions of the Creative Commons Attribution (CC BY) license (http://creativecommons.org/licenses/by/4.0/).

International Journal of Research in Business and Social Science (2147-4478) by SSBFNET is licensed under a Creative Commons Attribution 4.0 International License. 